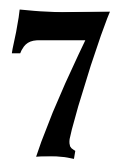

\title{
EMPLOYABILITY OF RECENT GRADUATES. OPINIONS OF CATALONIAN COMPANIES AND INSTITUTIONS ${ }^{1}$
}

\author{
(EMPLEABILIDAD DE LOS RECIÉN TITULADOS. \\ OPINIÓN DE LAS EMPRESAS E INSTITUCIONES CATALANAS)
}

Joan Guàrdia-Olmos

Maribel Peró-Cebollero

Mar Martínez-Ricart

Cristina Cañete-Massé

Jaume Turbany-Oset

Vanesa Berlanga-Silvente

Universitat de Barcelona

DOI: 10.5944/educXX1.19871

\section{Cómo referenciar este artículo/How to reference this article:}

Guàrdia-Olmos, J.; Peró-Cebollero, M.; Martínez-Ricart, M.; Cañete-Massé, C.; Turbany-Oset, J. y Berlanga-Silvente, V. (2018). Employability of recent graduates. Opinions of Catalonian companies and institutions. Educación XX1, 21(2), 155-177, doi: 10.5944/educXX1.19871

Guàrdia-Olmos, J.; Peró-Cebollero, M.; Martínez-Ricart, M.; Cañete-Massé, C.; Turbany-Oset, J. \& Berlanga-Silvente, V. (2018). Employability of recent graduates. Opinions of Catalonian companies and institutions. [Empleabilidad de los recién titulados. Opinión de las empresas e instituciones catalanas]. Educación XX1, 21(2), 155-177, doi: 10.5944/educXX1.19871

\section{ABSTRACT}

Introduction: Labor insertion for young people is probably more difficult nowadays than it was a few decades ago in all productive sectors and in academic education. A few decades ago, having a university degree was a guarantee of quick labor insertion, but nowadays, although having a university degree may somewhat alleviate the unemployment rate, it is still high among recent university graduates. In this paper, we show the differential profile of the companies who do hire recent graduates as compared to those who do not. Methodology: We worked with a sample of 1,325 employers from the business world of Catalonia, who were administered the questionnaire prepared adhoc during 2014. Results: The main results show that the more workers a 
company has, the higher the probability that they will hire recent graduates. Companies with a high percentage of graduated workers are more likely to hire recent graduates. Companies who are willing to work with Agency for the Quality of the University System of Catalonia hire more than those who are not. And finally, the service sector hires more than construction or industry. Conclusions: In the present study we have shown a differential pattern between the companies that hire recent graduates or not, a very important aspect because this could help define university policies to facilitate the transition to the labor market.

\section{KEY WORDS}

Labor insertion; recently graduated university students; employers; employability; university training.

\section{RESUMEN}

Introducción: La inserción laboral de los jóvenes, probablemente es más difícil hoy en día que unas décadas atrás, en todos los sectores y en todos los niveles de formación. Hace unas décadas, tener una titulación universitaria prácticamente era garantía de rápida inserción laboral, pero hoy en día, a pesar de que tener una titulación universitaria puede hacer descender el desempleo, éste es elevado también entre los recién titulados universitarios. En este trabajo, se muestra el perfil diferencial de las compañías que contratan a recién titulados en relación con las compañías que no los contratan. Metodología: Se ha trabajado con una muestra de 1.325 ocupadores del mundo laboral de Cataluña. Estos ocupadores, contestaron durante el 2014, un cuestionario preparado ex profeso para determinar los aspectos vinculados con la contratación de recién titulados. Resultados: Los principales resultados muestran que cuantos más trabajadores tiene una compañía, mayor es la probabilidad de que contraten a recién titulados. Compañías con un alto porcentaje de trabajadores que tienen titulación universitaria, presentan mayor probabilidad de contratar a recién titulados. Compañías que están dispuestas a trabajar con la Agència per a la Qualitat del Sistema Universitari de Catalunya (AQU), contratan más que las que no tienen esta disposición. Y finalmente, la contratación es mayor en el sector servicios que en los sectores de construcción o industria. Conclusiones: A partir del presente trabajo se ha podido detectar un patrón diferencial de compañías que contratan a recién licenciados, aspecto de suma importancia, puesto que puede ayudar a definir políticas universitarias de transición al mundo laboral.

\section{PALABRAS CLAVE}

Inserción laboral; universitarios recién graduados; ocupadores; empleabilidad; formación universitaria. 


\section{INTRODUCTION}

The labor insertion of young people may be considered the transition process from adolescence into adulthood (Arnau et al. 2014), as it implies that the person must take on new responsibilities which, up until then, fell on the parents or legal tutors. Therefore it can be considered as a turning point into adulthood, as it implies the ending of the training period to access the active life and, consequently, employment (Martínez-Rodríguez and Carmona-Orantes 2010).

This transition into the labor market has become more difficult in recent years due to the high general unemployment rate caused by the economic crisis, which has influenced certain age groups to a greater extent. One of these groups is the young people who are about to access the labor market for the first time (Verick 2009). This higher fragility in recent years for young people to access their first job is of great importance, as access to the first job is essential for the worker's employability path. (Banerjee et al. 2008).

It is worth mentioning that this difficulty to access the labor market is universal. For that reason, different strategies have been set in motion to try to alleviate this difficulty, and thus improve labor insertion rates. For example, the European Council adopted, in February 2013, an initiative to improve youth employment by assigning a budget of 6 billion euro for the 2014-2020 budget period (Communication of the European Commission, 2013). Another example is the implementation of territorial agents to revitalize labor insertion and territorial pacts in the province of Granada, Spain (Pérez-Sánchez et al. 2013). Yet another, more innovative strategy is the development of the work tutor, an intelligent virtual tutor tool for labor insertion which has advised over 5,000 Spanish youngsters residing in Germany, France, the United Kingdom, and Switzerland (Alonso-Ramos et al. 2015).

With regard to research, several studies have approached this topic. Some of them have studied how training affects employability (Corominas et al. 2012; Fachelli and Navarro-Cendejas, 2015; Fachelli et al. 2014; Jung et al. 2016; Silva et al. 2016). Therefore, Corominas et al. (2012) constructed an index to assess the occupational quality of recent university graduates (last three-five years) which, among other indicators, considers the perception of recent graduates on the adequacy between university training and the work carried out. Jung et al. (2016) studied the employment rate of youngsters in South Korea, and they showed that university students present a higher access rate to more prestigious jobs than youngsters without university studies. On the other hand, Fachelli et al. (2014) showed that going to college softens the social differences in labor insertion; and in their 2015 
paper (Fachelli and Navarro-Cendejas, 2015), they showed that this effect is maintained regardless of the degree they took.

Accordingly, in the case of Spain, as pointed out by Merino and García (2007), this implied higher access to university, especially after the 1960s, and mainly in the democracy period. Consequently, over one third of Spanish youngsters enter university nowadays. This aspect, which is positive with regard to the training of youngsters and therefore of the country's cultural level, also entails a harmful effect, as a great number of university graduates are overqualified for the job they have (Battu et al. 2000; Brynin 2002). Consequently, they are colonizing areas of the labor market that used to be occupied by people without a university degree (Tomlison 2008).

In any case, it should be noted that several papers show that having a university degree may no longer be considered a relevant advantage when accessing the labor market, and therefore the importance of having a university degree should be put into question before entering the university. Accordingly other aspects should see their value increased, like for example the recent graduates' competencies, skills, or social networks (Allen and Weert 2007; Arnau et al. 2014; Cai 2013; Gutierrez and de Pablos 2010; Kalfa and Taksa 2016; Martínez-Rodríguez, and CarmonaOrantes 2010; Schomburg 2007; Tomlison 2008). Consequently, several papers highlight the need to prepare the process of transition to the labor market by implementing training programs that focus on learning soft competencies, as well as employability skills (Berridge 2007; Dixon 2006, 2007; Mendes 2009). Internationalization can be a good form to prepare university students in soft competences and hence for work, because it contributes to the graduate's portfolio of employability skills (Crossman and Clarke 2010). Other works focuses on formal work integrated learning which exposes university students to professional ideology and practice in order to develop pre-professional identity among students (Jackson 2016). Or Silva et al. (2016) show how internship interaction with labor market during higher education studies reduces the unemployability rate, and also it is an advantage for employers that can see how the students work. Trede and McEwen (2105), also remarks the benefits to workplace learning early during the university studies in order persist with their learning and to improve the posterior employability.

Be that as it may, it should be pointed out that all of the studies mentioned so far focused on the point of view of the youngster trying to access the labor market. However, in the job hunting process to access the labor market for the first time, one should bear in mind the pair job-hunting recent graduate / employer, and even add to this pair the university trainer's viewpoint (Cai 2013; Crossman and Clarke 2010; Serrano et al. 2015; Sin and 
Amaral 2017). Brown and Hesketh (2004) showed that the importance given to university degrees by employers has decreased, whereas the importance they give to personal characteristics and people's skills has increased. Still, we should note it is not only about knowledge and personal skills, but also to what degree they fit the employer's requirements (Schöer et al. 2014). There are few papers trying to study this relationship, but they do not actually study the employer's viewpoint. Thus, Serrano et al. (2015) actually compared, for every competency studied, the educational level taught to how useful the students considered it for their professional development. For his part, Tomlison (2008) focused once again on the point of view of the students looking for their first job, and he came to the conclusion that they give great importance to soft credentials, that is, personal, social, and behavioral credentials. Martín, Rabadán and Hernández (2013), shows the little mismatches between the competencies needed from the employers' point of view and the level get for the university graduates in engineering sciences in Madrid.

Therefore, not many studies analyze the employer's point of view. For this reason, in the current paper, we intend to analyze which characteristics differentiate the employers who did hire recent graduates in the last five years from those who did not.

\section{METHOD}

\section{Participants}

The sample of the current study comprises a total of 1,325 occupiers from the business world of the autonomous community of Catalonia based on an accidental sampling.

$33.5 \%$ of the occupiers from the sample work in companies of 1-9 workers, while $36.7 \%$ work in companies of $10-50$ workers. $94.9 \%$ work in private companies, in $63.9 \%$ it is a one-branch company. Finally, the companies had been in business for an average of 26.80 years, with a standard deviation of 27.75 years, so the newest company was not even 1 year old, while the oldest had been in business for 316 years.

We compared the distribution by sector of activity according to the classification of CCAE 2009 (Catalan classification of economic activities) divided into three main groups - services, construction, and industrywith the Catalan business world in 2015 based on data from the IDESCAT (Institute of Statistics of Catalonia). The $\chi^{2}$ goodness of fit test shows that the sample studied does not present the same distribution as the Catalan 
business world $\left(\chi^{2}(2)=1,411.08 ; \mathrm{p}<.001\right)$, mainly because the industry sector is overrepresented in the sample.

\section{Instruments}

The instrument administered was a questionnaire prepared by AQU (Agency for the Quality of the University System of Catalonia). It comprises a total of 24 questions for those occupiers who did hire recent university graduates in the last five years, whereas it has 9 questions for those who did not. These questions may have sub-questions and they are organized into the seven following theme blocks:

- Block 1: company identification. In this block, aspects characterizing the company are researched, such as number of workers, years in business, or main activity.

- Block 2: hiring process. In this block, information is gathered regarding whether they have hired or not. The occupiers who have, are questioned about the educational sector in which they hired, the importance given to the different levels of university degree for hiring, as well as the difficulties they had during the hiring process.

- Block 3: competencies. This blocks comprises questions on the importance of different competencies recent university graduates must have (training, cognitive, personal management, instrumental, interpersonal, and ethical), as well as the degree of satisfaction with those competencies.

- Block 4: collaboration with the universities. In this block it is enquired whether the companies collaborate with the universities in different activities and on different measures the universities might take to improve employability.

- Block 5: company strategy. In this block, the company's management of human resources is investigated, as well as their productive activity.

- Block 6: companies who have not hired recent university graduates. In this block the reasons are enquired as to why they have not hired recent graduates in the last five years.

- Block 7: information of the person answering the questionnaire.

Blocks 1 and 7 had to be answered by all the respondents, whereas blocks 2, 3, 4, and 5 were only answered by the occupiers who had hired recent university degrees in the last five years, and block 6 only by those who had not. The questionnaire can be found on this link http://www.aqu.cat/ estudis/ocupadors/index.html\#.WLWN8k0zUpF, or else it can be requested at the following e-mail address: infor@aqu.cat. 


\section{Procedure}

The questionnaire was administered to the sample of occupiers previously mentioned between October and December 2014. 40.3\% of the surveys was collected via e-mail, whereas $59.7 \%$ was collected via telephone. The person answering the questionnaire was different in every case. In any case, in $27.09 \%$ of the cases it was the CEO or manager, in $22.86 \%$ it was the manager or head of human resources, and in $10.5 \%$, the heads of departments.

\section{Data analysis}

The data analysis involved the description of the sample's main variables. For those items of the questionnaire grouped by construct and formulated in a Likert scale, we conducted their psychometric study, basically as regards the obtention of the items' discrimination index, reliability index as internal consistency based on Cronbach's alpha coefficient, and construct validity study based on a confirmatory factor analysis for each construct. More specifically, we analyzed the following constructs:

- Importance of university training for hiring, comprising 4 items (question 12 of block 2).

- Importance of competencies, comprising 15 items (question 15 of block 3).

- Degree of satisfaction with the competencies acquired by recent university graduates, comprising 15 items (question 16 of block 3).

- Collaboration with universities, comprising 5 items (question 19 of block 4).

- Measures of the universities to improve employability, comprising 4 items (question 20 of block 4).

- Innovations in the company's productive activity, comprising 5 items (question 23 of block 5).

- Management of human resources, comprising 4 items (question 24 of block 5).

Finally, bearing in mind those variables which were related to hiring, we conducted different logistic regressions in order to determine the variables which could determine the profile of the companies who had hired recent university graduates in the last five years. All the analyses were conducted with the IBM SPSS Statistics software, version 23, and with the MPLUS software, version 5.0 (Muthén and Muthén 2007). 


\section{RESULTS}

\section{Descriptive statistic}

Out of the 1,325 interviews we collected among the occupiers, we should note that, in 722 cases, recent graduates had been hired in the last five years; in 505, recent graduates had not been hired, and in 98 cases the information was unavailable. Out of the companies who had hired, information was available on the number of recent graduates hired in the last five years for 676 companies, where the mean was 12.01 recent graduates hired with a standard deviation of 45.17 . This reveals the great variability in the number of recent graduates hired by the companies in the sample. In any case, we should point out that $90 \%$ of the companies in the sample had hired a maximum of 20 recent graduates in the last five years. Among the companies who hired recent graduates in the last five years, the education fields with most hirings were: Economy, Business Management, Production Engineering, and ICTs (table 1).

Table 1

Description of recent graduates hired according to education fields $(n=722)$

\begin{tabular}{|c|c|c|c|}
\hline Education field & Hires & Does not hire & $\begin{array}{l}\text { DK/NA or not } \\
\text { applicable }\end{array}$ \\
\hline Humanities, history, art & $34(4.7 \%)$ & $685(94.9 \%)$ & $3(0.4 \%)$ \\
\hline Language & $19(2.6 \%)$ & $700(97.0 \%)$ & $3(0.4 \%)$ \\
\hline Economy, business management & $248(34.3 \%)$ & $471(65.2 \%)$ & $3(0.4 \%)$ \\
\hline $\begin{array}{l}\text { Law, sociology, labor relations, social } \\
\text { work, politics }\end{array}$ & $88(12.2 \%)$ & $631(87.4 \%)$ & $3(0.4 \%)$ \\
\hline Communication, documentation & $110(15.2 \%)$ & $609(84.3 \%)$ & $3(0.4 \%)$ \\
\hline Psychology, pedagogy, psychopedagogy & $31(4.3 \%)$ & $688(95.3 \%)$ & $3(0.4 \%)$ \\
\hline Teaching and social education & $3(0.4 \%)$ & $716(99.2 \%)$ & $3(0.4 \%)$ \\
\hline Tourism & $23(3.2 \%)$ & $696(96.4 \%)$ & $3(0.4 \%)$ \\
\hline $\begin{array}{l}\text { Experimental science: chemistry, } \\
\text { environmental }\end{array}$ & $74(10.2 \%)$ & $645(89.3 \%)$ & $3(0.4 \%)$ \\
\hline Health & $12(1.7 \%)$ & $707(97.9 \%)$ & $3(0.4 \%)$ \\
\hline Medicine and odontology & $1(0.1 \%)$ & $718(99.4 \%)$ & $3(0.4 \%)$ \\
\hline Pharmacy, science, food technology & $31(4.3 \%)$ & $688(95.3 \%)$ & $3(0.4 \%)$ \\
\hline Architecture and civil engineering & $62(8.6 \%)$ & $657(91.0 \%)$ & $3(0.4 \%)$ \\
\hline $\begin{array}{l}\text { Production engineering (industrial, } \\
\text { chemical, etc.) }\end{array}$ & $221(30.6 \%)$ & $498(69.0 \%)$ & $3(0.4 \%)$ \\
\hline ICT (IT, telecommunications, electronics) & $198(27.4 \%)$ & $521(72.2 \%)$ & $3(0.4 \%)$ \\
\hline Agricultural engineering & $20(2.8 \%)$ & $699(96.8 \%)$ & $3(0.4 \%)$ \\
\hline
\end{tabular}


In the hiring process, out of the 722 companies who had hired a recent graduate in the last five years, $85.2 \%$ value the fact of having a specific degree, but when asked about a master's degree or $\mathrm{PhD}$, the percentage drops drastically to $19 \%$ and $4 \%$ respectively. Additionally, we should note that $41.8 \%$ of these companies expressed their difficulty in hiring the right person for a specific job, mainly due to the lack of recent graduates with the necessary competencies for that job (40.1\%) and the lack of graduates in a specific field $(29.8 \%)$.

As for the 505 companies who had not hired recent graduates in the last five years, they gave the following reasons for not doing so: there were no vacancies in the company (52.5\%); or they did not need workers with that level of qualification $(34.7 \%)$ - the latter reason might be linked to the fact that the industrial sector is overrepresented in the sample studied. Possibly, this sector requires workers with a lower level of qualification than university.

\section{Psychometric study}

Table 2 shows the value of Cronbach's alpha coefficient for the reliability study as internal consistency along with the range of the discrimination index of the items for each construct analyzed. We should note that reliability is adequate for four constructs, since the values of Cronbach's alpha coefficient are over 0.70 , or even excellent in some cases, as the study presents Cronbach's alpha values of over 0.85 (Muñiz 2005).

Table 2

Cronbach's alpha coefficient and discrimination index

\begin{tabular}{lcccc}
\hline \multicolumn{1}{c}{ Construct } & $\mathbf{n}$ & $\begin{array}{c}\text { N. } \\
\text { items }\end{array}$ & a & DI \\
\hline Importance of university education in hiring & 592 & 4 & .652 & $.363-.506$ \\
Importance of competencies & 691 & 15 & .862 & $.222-.645$ \\
Degree of satisfaction with the competencies & 633 & 15 & .939 & $.493-.835$ \\
acquired by recent graduates & 694 & 5 & .712 & $.375-.532$ \\
Collaboration with the universities & 691 & 4 & .714 & $.453-.583$ \\
Measures of the universities to improve & 624 & 5 & .646 & $.328-.456$ \\
employability & 631 & 4 & .565 & $.266-.400$ \\
Innovations in the company's productive activity & 624 & &
\end{tabular}

$\alpha$ : value of Cronbach's alpha coefficient; DI: minimum and maximum value of the discrimination index in each construct analyzed.

Source: self elaboration. 
In table 3, we can see the fit indices of the seven confirmatory factor analyses to assess each construct's unidimensionality. The estimation of the fits of the confirmatory factor models was conducted based on Pearson's correlation matrices with estimations based on maximum likelihood (ML). Therefore, in the seven analyses conducted, they were exogenous measurement models with the following structure: $\left[\mathrm{X}_{\mathrm{i}}=\Lambda_{\mathrm{x}} \xi_{\mathrm{j}}+\varepsilon_{\mathrm{i}}\right]$ (Loehlin 2004).

Table 3

Fit indices of the univariate confirmatory factor analysis

\begin{tabular}{|c|c|c|c|c|c|c|c|}
\hline Construct & $\begin{array}{c}\text { N. } \\
\text { items }\end{array}$ & $\chi^{2}$ & CFI & TLI & AIC & BIC & $\begin{array}{c}\text { RMSR } \\
\text { (IC) }\end{array}$ \\
\hline $\begin{array}{l}\text { Importance of university } \\
\text { education in hiring }\end{array}$ & 4 & $\begin{array}{l}423.72 \\
\mathrm{p}=.13\end{array}$ & .934 & .914 & -1.246 .12 & -1.276 .13 & $.04(.03-.05)$ \\
\hline $\begin{array}{l}\text { Importance of } \\
\text { competencies }\end{array}$ & 15 & $\begin{array}{l}259.45 \\
\mathrm{p}=.08\end{array}$ & .949 & .927 & -1.577 .19 & -1.591 .23 & $.05(.04-.06)$ \\
\hline $\begin{array}{l}\text { Degree of satisfaction with } \\
\text { the competencies acquired by } \\
\text { recent graduates }\end{array}$ & 15 & $\begin{array}{l}352.17 \\
\mathrm{p}=.25\end{array}$ & .919 & .939 & -2.123 .11 & -2.155 .19 & $.04(.03-.05)$ \\
\hline $\begin{array}{l}\text { Collaboration with the } \\
\text { universities }\end{array}$ & 5 & $\begin{array}{l}871.12 \\
\mathrm{p}=.36\end{array}$ & .926 & .945 & -1.799 .34 & -1.820 .21 & $.03(.02-.04)$ \\
\hline $\begin{array}{l}\text { Measures of the universities } \\
\text { to improve employability }\end{array}$ & 4 & $\begin{array}{l}548.22 \\
\mathrm{p}=.18\end{array}$ & .922 & .953 & -1.221 .09 & -1.262 .34 & $.04(.03-.05)$ \\
\hline $\begin{array}{l}\text { Innovations in the } \\
\text { company's productive } \\
\text { activity }\end{array}$ & 5 & $\begin{array}{l}732.48 \\
\mathrm{p}=.14\end{array}$ & .939 & .948 & -1.659 .21 & -169.02 & $.05(.04-.06)$ \\
\hline $\begin{array}{l}\text { Management of human } \\
\text { resources }\end{array}$ & 4 & $\begin{array}{l}433.87 \\
\mathrm{p}=.19\end{array}$ & .932 & .922 & -1.492 .16 & -1.497 .14 & $.03(.02-.04)$ \\
\hline
\end{tabular}

$\chi^{2}$ : value of the chi-square fit index and p-value; CFI: Comparative Fit Index; TLI: Tucker Lewis Index; AIC: Akaike Criteria; BIC: Bayesian Criteria; RMSE (IC): root mean square error and confidence interval of the RMSE with a 95\% confidence level.

Source: self elaboration.

As can be seen in the table, we can assume a sufficient fit (CFI, TLI close to 1, and RMSR below .06; Hu and Bentler 1999; Schumacker and Lomax 1996) as to assume that each latent variable is formed by the items indicated. Therefore there is sufficient construct validity to generate each construct's scores.

Despite the analyses conducted, we can assume the unidimensionality of the seven constructs analyzed. Therefore, we proceeded to obtain the score 
of each construct based on the summation of each item's score and then, in order to work with the same scale in the seven constructs, the total score was transformed in to $\mathrm{z}$ score based on the mean and the standard deviation observed in each construct. Accordingly, for the remaining analyses, we worked with this score and not with the direct assessment of the items.

\section{Modelization based on logistic regressions}

As has been pointed out, based on the logistic regression, we intend to determine which variables may discriminate among the companies who do hire recent university graduates and those who do not. Therefore, for this analysis, we took into account as predictor variables those which were statistically related to the fact of hiring recent graduates or not in the last five years in a bivariant analysis, and which are listed below:

- Number of workers of the company $\left(\chi^{2}(7)=130.808 ; p<.001\right.$; $V=.291)$.

- Percentage of workers with a university degree $\left(\chi^{2}(9)=160.578\right.$; $p<.001 ; V=.380)$.

- Years in business $(t(1161)=3.625 ; p<.001 ; r=.105)$.

- One-branch company $\left(\chi^{2}(1)=28.044 ; p<.001 ; V=.151\right)$.

- Company's main activity (services, industry and construction) $\left(\right.$ CCAE-2009) $\left(\chi^{2}(2)=43.46 ; p<.001 ; V=.191\right)$.

- Collaboration with AQU $\left(\chi^{2}(1)=26.93 ; p<.001 ; V=.151\right)$.

In addition to the global model, the same model was fitted for the different education fields, that is, humanities, social sciences and education, health, experimental sciences, and technical sciences. For the five logistic regression models fitted, we followed the stepwise forward conditional parameter estimation model in order to establish the most parsimonious possible model.

As can be seen in table 4, the five models present a good fit, given that the omnibus test shows that the coefficients estimated are statistically significant. Also the Hosmer-Lemeshow test indicates that the fit is adequate, as it is not statistically significant, even though for the areas of humanities, health, and experimental sciences, it is not recommended to interpret the latter test, as the application condition was not met. On the other hand, if we pay attention to the percentage of variability explained by the model, we can consider it adequate for the global model, but not for the different educational areas (table 5). Therefore, we are only displaying the estimation of the regression coefficients of the variables of the definitive model for the global model (table 6). 
Table 4

Goodness-of-fit measurements for the five models proposed $(n=974)$

\begin{tabular}{|c|c|c|c|c|c|c|c|c|c|c|}
\hline \multirow{2}{*}{ Model } & \multirow{2}{*}{$\begin{array}{l}\text { N. } \\
\text { steps }\end{array}$} & \multicolumn{3}{|c|}{ Omnibus test } & \multicolumn{3}{|c|}{$\begin{array}{l}\text { Hosmer- } \\
\text { Lemeshow }\end{array}$} & \multirow[t]{2}{*}{$-2 \mathrm{LL}$} & \multirow{2}{*}{$\begin{array}{l}\mathbf{R}^{2} \\
\mathbf{C}-\mathbf{S}\end{array}$} & \multirow{2}{*}{$\begin{array}{l}\mathbf{R}^{2} \\
\mathbf{N}\end{array}$} \\
\hline & & $\chi^{2}$ & df & $\mathbf{p}$ & $\chi^{2}$ & df & $\mathbf{p}$ & & & \\
\hline Global & 5 & 245.94 & 19 & $<.001$ & 8.09 & 8 & .425 & 1.016 .65 & .223 & .307 \\
\hline Humanities* & 2 & 49.51 & 11 & $<.001$ & 4.88 & 7 & .674 & 309.02 & .050 & .161 \\
\hline $\begin{array}{l}\text { Social sciences and } \\
\text { education }\end{array}$ & 4 & 164.17 & 18 & $<.001$ & 4.36 & 8 & .824 & 1.070 .62 & .155 & .216 \\
\hline $\begin{array}{l}\text { Health and experi- } \\
\text { mental sciences* }\end{array}$ & 3 & 122.25 & 17 & $<.001$ & 5.23 & 8 & .733 & 482.42 & .118 & .255 \\
\hline Technical sciences & 3 & 118.33 & 16 & $<.001$ & 11.50 & 8 & .175 & 1.183 .62 & .114 & .155 \\
\hline
\end{tabular}

$\mathrm{N}$ steps: Number of steps in the estimation; -2LL: -2 likelihood logarithm; $\mathrm{R}^{2} \mathrm{C}-\mathrm{S}$ : r-square Cox and Snell value; $\mathrm{R}^{2} \mathrm{~N}$ : r-square Naglekerke value.

* In these cases, the application condition is not met in order to interpret the Hosmer-Lemeshow goodness-of-fit test, as there are expected frequencies below five.

Source: self elaboration.

Table 5

Correct classifications percentage for the five fitted models $(n=974)$

\begin{tabular}{l|ccc}
\hline \multirow{2}{*}{ Model } & \multicolumn{3}{c}{ Correct classifications } \\
\cline { 2 - 4 } & Total & Hire & Do not hire \\
\hline $\begin{array}{l}\text { Global } \\
\text { Humanities }\end{array}$ & $72.6 \%$ & 532 out of $632(84.2 \%)$ & 175 out of $242(51.2 \%)$ \\
$\begin{array}{l}\text { Social sciences and } \\
\text { education }\end{array}$ & $72.5 \%$ & 0 out of $44(0.0 \%)$ & 930 out of $930(100.0 \%)$ \\
$\begin{array}{l}\text { Health and experimental of } 321(34.9 \%) \\
\text { sciences }\end{array}$ & $90.8 \%$ & 894 out of $653(91.0 \%)$ \\
Technical sciences & $67.4 \%$ & 126 out of $379(33.2 \%)$ & 530 out of $595(89.1 \%)$ \\
\hline
\end{tabular}

Source: self elaboration.

As can be seen in table 6, all the variables included in the model - except for the one-branch company variable—are statistically significant. As the table shows, as the number of workers of the company increases, so does the odds ratio value $[\operatorname{Exp}(b)]$. Accordingly, the higher the number of workers in the company, the higher the probability that they will hire recent graduates, if we take companies with 1-9 workers as a reference. In 
any case, we should note that, in certain cases, the trust interval related to the odds ratio is very wide, which shows the little precision of the punctual estimation. This might be due to the small sample size in certain values of the variable. For the variable 'percentage of workers with a university degree in the company', we should note that the companies with $61-70 \%$ and $81-90 \%$ workers with a university degree are the ones most likely to hire recent graduates, if we take as a reference companies with 1-9\% workers with a university degree. As regards the will to collaborate with AQU, we should point out that for every two recent graduates hired by the companies who do not wish to collaborate with AQU, over 3 are hired by the ones who do wish to collaborate (odds ratio $=1.625$ ). With respect to the company's main activity, despite the fact that, globally, the variable is statistically significant, it can actually be attributed to the comparison between the construction sector and the services sector. Accordingly, for every recent graduate hired in the construction sector, two are hired in the services sector (odds ratio $=0.462$ ). Lastly, regarding the company's years in business, with a very low effect, it can be stated that the more years in business of the company, the fewer recent graduates they hire (odds ratio $=0.993)$.

The logistic regression model did not have adequate predictor variables if the model was fitted by educational area. In addition, other variables besides the previous six were statistically significant if the bivariant analysis distinguished whether they hired or not in the different educational areas among the companies who had hired recent graduates in the last five years. For this reason, we decided to fit the logistic regression model for these four areas, adding the following variables to the six previous ones.

- Importance of having a specific degree (humanities: $\chi^{2}{ }_{\text {Yates }}(1)=$ 28.04; $\mathrm{p}<.001 ; \mathrm{V}=.151$ ).

- Importance of having a master's degree (social sciences and education: $\chi^{2}(2)=15.42 ; \mathrm{p}<.001 ; \mathrm{V}=.315$; health and experimental sciences: $\chi^{2}(2)=8.87 ; \mathrm{p}=.012 ; \mathrm{V}=.113$, and technical sciences: $\left.\chi^{2}(2)=9.13 ; \mathrm{p}=.010 ; \mathrm{V}=.115\right)$.

- Importance of having a $\mathrm{PhD}$ (social sciences and education: $\chi^{2}(1)=$ $7.92 ; \mathrm{p}=.005 ; \mathrm{V}=.111$, and health and experimental sciences: $\left.\chi^{2}(1)=7.82 ; \mathrm{p}=.005 ; \mathrm{V}=.121\right)$.

- Importance of university education in hiring (humanities: $\mathrm{t}(588)=$ 1.962; $\mathrm{p}=.050 ; \mathrm{r}=.081$, and social sciences and education: $\mathrm{t}(588)=$ 2.242; $\mathrm{p}=.025 ; \mathrm{r}=.092)$.

- Collaboration with the universities (social sciences and education: $\mathrm{t}(690)=3.929 ; \mathrm{p}<.001 ; \mathrm{r}=.148$, health and experimental sciences: $\mathrm{t}(690)=2.936 ; \mathrm{p}=.003 ; \mathrm{r}=.111)$. 
Table 6

Regression coefficients of the predictor variables for the global model $(n=974)$

\begin{tabular}{|c|c|c|c|c|c|c|c|c|}
\hline \multirow{2}{*}{ Variables } & \multirow{2}{*}{ B } & \multirow{2}{*}{ SE } & \multicolumn{3}{|c|}{ Wald's test } & \multirow{2}{*}{$\operatorname{Exp}(B)$} & \multicolumn{2}{|c|}{ 95\% CI EXP(B) } \\
\hline & & & $\chi^{2}$ & df & $\mathbf{p}$ & & Lower & Upper \\
\hline No workers & & & 58.51 & 6 & .000 & & & \\
\hline $10-50$ respect $1-9$ & 0.615 & 0.197 & 9.77 & 1 & .002 & 1.850 & 1.258 & 2.720 \\
\hline $51-100$ respect $1-9$ & 1.150 & 0.279 & 17.02 & 1 & .000 & 3.159 & 1.829 & 5.457 \\
\hline $101-200$ respect $1-9$ & 2.185 & 0.396 & 30.38 & 1 & .000 & 8.888 & 4.087 & 19.327 \\
\hline 201-250 respect 1-9 & 2.889 & 0.783 & 13.61 & 1 & .000 & 17.973 & 3.873 & 83.398 \\
\hline $251-500$ respect $1-9$ & 3.577 & 1.071 & 11.15 & 1 & .001 & 35.775 & 4.383 & 292.041 \\
\hline$>500$ respect $1-9$ & 2.826 & 0.787 & 12.89 & 1 & .000 & 16.885 & 3.610 & 78.986 \\
\hline $\begin{array}{l}\text { Percentage of workers with } \\
\text { a university degree }\end{array}$ & & & 92.10 & 9 & .000 & & & \\
\hline $11-20 \%$ respect $1-10 \%$ & 0.851 & 0.267 & 10.14 & 1 & .001 & 2.342 & 1.387 & 3.956 \\
\hline $21-30 \%$ respect $1-10 \%$ & 0.540 & 0.293 & 3.40 & 1 & .065 & 1.716 & .967 & 3.046 \\
\hline $31-40 \%$ respect $1-10 \%$ & 0.760 & 0.325 & 5.46 & 1 & .020 & 2.137 & 1.130 & 4.043 \\
\hline $41-50 \%$ respect $1-10 \%$ & 1.269 & 0.303 & 17.51 & 1 & .000 & 3.557 & 1.963 & 6.443 \\
\hline $51-60 \%$ respect $1-10 \%$ & 1.106 & 0.337 & 10.81 & 1 & .001 & 3.023 & 1.563 & 5.847 \\
\hline $61-70 \%$ respect $1-10 \%$ & 2.771 & 0.522 & 28.12 & 1 & .000 & 15.971 & 5.736 & 44.471 \\
\hline $71-80 \%$ respect $1-10 \%$ & 1.368 & 0.342 & 16.04 & 1 & .000 & 3.928 & 2.011 & 7.674 \\
\hline $81-90 \%$ respect $1-10 \%$ & 2.713 & 0.427 & 40.28 & 1 & .000 & 15.076 & 6.523 & 34.847 \\
\hline $91-100 \%$ respect $1-10 \%$ & 2.283 & 0.289 & 62.22 & 1 & .000 & 9.807 & 5.561 & 17.293 \\
\hline $\begin{array}{l}\text { Collaboration AQU (Yes } \\
\text { respect No) }\end{array}$ & 0.486 & 0.168 & 8.32 & 1 & .004 & 1.625 & 1.168 & 2.261 \\
\hline CCAE (Main activity) & & & 7.48 & 2 & .024 & & & \\
\hline $\begin{array}{l}\text { Construction respect } \\
\text { Services }\end{array}$ & -0.772 & 0.289 & 7.11 & 1 & .008 & 0.462 & 0.262 & 0.815 \\
\hline Industry respect Services & -0.227 & 0.188 & 1.46 & 1 & .227 & 0.797 & 0.551 & 1.152 \\
\hline Years in business & -0.007 & 0.003 & 5.70 & 1 & .017 & 0.993 & 0.987 & 0.999 \\
\hline Constant & -1.163 & 0.267 & 18.92 & 1 & .000 & 0.312 & & \\
\hline
\end{tabular}

B: regression coefficient value; SE: standard error coefficient value; CCAE: Catalan classification of economic activities.

Source: self elaboration.

The first three are qualitative variables whereas the latter two are quantitative in ratio scale given that they are the $\mathrm{z}$ scores of the two constructs generated. For the four models fitted, the sample size is smaller $(n=482)$ 
because, as has already been mentioned, the information for these variables exists only in those companies who had hired recent graduates in the last five years. Tables 7 and 8 show the models' goodness-of-fit measurements and the percentage of correct classifications, respectively.

The four models can be considered valid as the omnibus test was statistically significant, which indicates that the coefficients estimated are statistically significant globally. In any case, the r-square Cox and Snell value, as well as the Nagelkerke, are not very high. On the other hand, the Hosmer-Lemeshow goodness-of-fit test reveals good fit for the four models, except for the area of humanities. In that case, though, this test should not be interpreted, as the application condition is not met. Such is the case, too, for the area of health and experimental sciences (table 7).

If we pay attention to the percentage of correct classifications (table 8), despite the fact that, globally, the percentages are high and very good for the area of humanities and the area of health and experimental sciences, the value is very low in the group of companies who did hire. Out of the four models, the one for the area of social sciences and education presents a moderate fit. Accordingly, for this educational area, table 9 shows the estimation of the model's coefficients in the predictor variables included.

Table 7

Goodness-of-fit measurements for the four models fitted $(n=482)$

\begin{tabular}{|c|c|c|c|c|c|c|c|c|c|c|}
\hline \multirow{2}{*}{ Model } & \multirow{2}{*}{$\begin{array}{l}\text { N. } \\
\text { steps }\end{array}$} & \multicolumn{3}{|c|}{ Omnibus test } & \multicolumn{3}{|c|}{$\begin{array}{c}\text { Hosmer- } \\
\text { Lemeshow }\end{array}$} & \multirow{2}{*}{$-2 \mathrm{LL}$} & \multirow{2}{*}{$\begin{array}{l}\mathbf{R}^{2} \\
\mathbf{C - S}\end{array}$} & \multirow[t]{2}{*}{$\mathbf{R}^{2} \mathbf{N}$} \\
\hline & & $\chi^{2}$ & df & $\mathbf{p}$ & $\chi^{2}$ & df & $\mathbf{p}$ & & & \\
\hline Humanities* & 2 & 17.02 & 4 & $<.001$ & 8.90 & 3 & .031 & 207.68 & .035 & .093 \\
\hline $\begin{array}{l}\text { Social sciences } \\
\text { and education }\end{array}$ & 5 & 83.66 & 12 & $<.001$ & 7.92 & 8 & .442 & 583.86 & .159 & .213 \\
\hline $\begin{array}{l}\text { Health and } \\
\text { experimental } \\
\text { sciences* }\end{array}$ & 4 & 81.11 & 6 & $<.001$ & 12.93 & 8 & .114 & 311.16 & .155 & .278 \\
\hline $\begin{array}{l}\text { Technical } \\
\text { sciences }\end{array}$ & 3 & 27.60 & 5 & $<.001$ & 12.54 & 8 & .129 & 617.98 & .056 & .075 \\
\hline
\end{tabular}

$\mathrm{N}$ steps: Number of steps in the estimation; -2LL: -2 likelihood logarithm; $\mathrm{R}^{2} \mathrm{C}-\mathrm{S}$ : r-square Cox and Snell value; $\mathrm{R}^{2} \mathrm{~N}$ : r-square Naglekerke value.

* In these cases, the application condition is not met in order to interpret the Hosmer-Lemeshow goodness-of-fit test, as there are expected frequencies below five.

Source: self elaboration. 
Table 8

Correct classification percentages for the four models fitted $(n=482)$

\begin{tabular}{l|ccc}
\hline \multirow{2}{*}{ Model } & \multicolumn{3}{c}{ Correct classifications } \\
\cline { 2 - 4 } & Total & Hire & Do not hire \\
\hline Humanities & $93.8 \%$ & 0 de 30 $(0.0 \%)$ & 452 de $452(100.0 \%)$ \\
Social sciences and education & $66.0 \%$ & 112 de $232(61.2 \%)$ & 176 de $250(70.4 \%)$ \\
Health and experimental sciences & $86.7 \%$ & 7 de $68(10.3 \%)$ & 411 de 414 $(99.3 \%)$ \\
Technical sciences & $63.5 \%$ & 261 de 293 $(89.1 \%)$ & 45 de 189 $(23.8 \%)$ \\
\hline
\end{tabular}

Source: self elaboration.

Table 9

Regression coefficients of the predictor variables for the social sciences and education model $(n=482)$

\begin{tabular}{|c|c|c|c|c|c|c|c|c|}
\hline \multirow{2}{*}{ Variables } & \multirow{2}{*}{$\mathbf{B}$} & \multirow{2}{*}{$\begin{array}{c}\text { Standard } \\
\text { error }\end{array}$} & \multicolumn{3}{|c|}{ Wald's test } & \multirow{2}{*}{$\operatorname{Exp}(B)$} & \multicolumn{2}{|c|}{ 95\% C.I. EXP(B) } \\
\hline & & & $\chi^{2}$ & df & $\mathbf{p}$ & & Lower & Upper \\
\hline No workers & & & 24.38 & 6 & .000 & & & \\
\hline $10-50$ respect $1-9$ & 0.502 & 0.249 & 4.04 & 1 & .044 & 1.651 & 1.013 & 2.693 \\
\hline $51-100$ respect $1-9$ & 1.432 & 0.371 & 14.86 & 1 & .000 & 4.186 & 2.022 & 8.667 \\
\hline $101-200$ respect $1-9$ & 1.582 & 0.410 & 14.87 & 1 & .000 & 4.865 & 2.177 & 10.871 \\
\hline $201-250$ respect $1-9$ & .614 & 0.591 & 1.08 & 1 & .299 & 1.848 & 0.581 & 5.881 \\
\hline $251-500$ respect $1-9$ & .666 & 0.672 & 0.98 & 1 & .322 & 1.946 & 0.521 & 7.271 \\
\hline Over 500 respect $1-9$ & 1.461 & 0.607 & 5.79 & 1 & .016 & 4.312 & 1.311 & 14.181 \\
\hline CCAE (Main activity) & & & 29.89 & 2 & $<.001$ & & & \\
\hline $\begin{array}{l}\text { Construction respect } \\
\text { Services }\end{array}$ & -1.324 & 0.484 & 7.49 & 1 & .006 & 0.266 & 0.103 & 0.687 \\
\hline $\begin{array}{l}\text { Industry respect } \\
\text { Services }\end{array}$ & -1.321 & 0.256 & 26.58 & 1 & .000 & 0.267 & 0.162 & 0.441 \\
\hline Years in business & 0.011 & 0.004 & 5.93 & 1 & .015 & 1.011 & 1.002 & 1.020 \\
\hline $\begin{array}{l}\text { Importance of having } \\
\text { a PhD }\end{array}$ & & & 7.32 & 2 & .026 & & & \\
\hline Yes respect No & -2.951 & 1.096 & 7.25 & 1 & .007 & 0.052 & 0.006 & 0.448 \\
\hline $\begin{array}{l}\text { In certain places } \\
\text { respect No }\end{array}$ & 0.124 & 0.560 & 0.05 & 1 & .825 & 1.132 & 0.378 & 3.393 \\
\hline $\begin{array}{l}\text { Collaboration with the } \\
\text { universities }\end{array}$ & 0.244 & 0.112 & 4.76 & 1 & .029 & 1.277 & 1.025 & 1.590 \\
\hline Constant & -0.431 & 0.175 & 6.05 & 1 & .014 & 0.650 & & \\
\hline
\end{tabular}

B: regression coefficient value; SE: standard error coefficient value; CCAE: Catalan classification of economic activities.

Source: self elaboration. 
As can be seen in table 9, there are five predictor variables which are statistically significant in predicting whether the companies hired recent graduates or not in the area of social sciences and education. As regards the variable 'number of workers of the company', we can say that as it increases - up to a size of 200 workers-, so does the probability of hiring recent graduates. Therefore, for every recent graduate hired in companies of 1-9 workers, almost five are hired in companies of 101-200 workers (odds ratio $=4.865$ ). With regard to the company's main activity, we can say that for every recent graduate hired in construction, almost 4 are hired in services (odds ratio $=0.266$ ). The same can be said when comparing industry to services (odds ratio $=0.267$ ). Regarding the variable 'years in business', despite the effect being very low, we can say that the more years in business, the higher the probability of hiring recent graduates (odds ratio $=1.011$ ). As for the variable 'importance of having a PhD', we can say that for every recent graduate hired in the group with a $\mathrm{PhD}, 20$ are hired in the group without a $\mathrm{PhD}$ (odds ratio $=0.052$ ). In any case, we should mention that the accuracy of the score estimation of the odds ratio is very low given the width of its trust interval. Lastly, regarding the construct 'collaboration with the universities', despite a very low effect (odds ratio $=1.277$ ), we can say that the more the companies collaborate with the universities, the more they hire recent graduates.

\section{CONCLUSIONS}

In the current study we have shown the main characteristics that help to discriminate between the companies who have hired recent university graduates in the last five years and those who have not. To do so, we opted for the logistic regression as an analysis technique. We should note that, out of the nine logistic regression models fitted, only the global model presents good fit, with $72.6 \%$ of correct classifications. However, if we pay attention to the two groups within the companies who have hired recent graduates in the last five years, the percentage of correct classifications is $84.2 \%$, whereas it is $51.2 \%$ among the companies who have not. For this reason the model has better sensitivity than specificity. The following conclusions can be inferred regarding this model: we can say that the more workers the company has, the higher the probability of hiring recent university graduates; the companies with a high percentage of workers with a university degree hire more recent university graduates; those companies who intend to collaborate with AQU hire more than those who do not want to collaborate with AQU; the services sector hires more than the construction sector; and the more years the company has been in business, the less they hire, although the latter is a very low intensity effect. 
As regards the model fitted in the area of social sciences and education, in those companies who have hired recent university graduates in the last five years in general, it may be considered to have an acceptable fit, given that it obtains $66 \%$ of correct classifications. On the other hand, the percentage is $61.2 \%$ among the companies who hire in this area, and $70.4 \%$ among the companies who do not hire in this area. Therefore, in this case, the model's specificity is better than its sensitivity, although neither value is very high. The following main conclusions can be stated for this model: as the number of workers increases, so does the probability that the company will hire recent university graduates - as it happened in the general model-; more recent graduates are hired in the services sector than in construction or industry -in the global model, it only occurred with regard to the construction sector-; the more years the company has been in business, the bigger the probability to hire - contrary to what is observed in the global model; the companies in this area hire more recent university graduates in the last five years without a $\mathrm{PhD}$ than with a PhD; and the companies who intend to collaborate more with the universities hire more than those who do not collaborate.

The results obtained in the present paper agree with what Schöer et al. (2014) or Sin and Amaral (2017) pointed out regarding the fact that the probability of being hired increases as does the company's size. As for the other variables, we cannot compare this to other studies as they have not been analyzed. Like Sin and Amaral (2017), our results also show the low collaboration between employers and higher educational institution in order to improve employability.

In any case, the results obtained in this study should be taken cautiously, given that - as we have already mentioned - the sample is not representative of the Catalan business world and the industry sector is overrepresented, which may be considered a limitation of the study. However, on the other hand, it should be noted that this is one of the few studies which present the opinion of employers regarding the competencies recent university graduates should have, which is relevant to generate employability policies.

\section{NOTAS}

1 This study was supported by a grant of the Agència per a la Qualitat del Sistema Universitari de Catalunya (AQU) and was done by some members of the Grup de Recerca en Tècniques Estadístiques Avançades Aplicades a la Psicologia (GTEAAP) and members of the Generalitat de Catalunya's 2014 SGR 326 Consolidated Research Group (GRC). 


\section{BIBLIOGRAPHIC REFERENCES}

Allen, J., \& de Weert, E. (2007). What Do Educational Mismatches Tell Us About Skill Mismatches? A Crosscountry Analysis. European Journal of Education, 42 (1), 59-73.

Alonso-Ramos, N., PereiraFariña, X., \& Punín-Larrea, M.I. (2015). WorkerTutor Design and implementation of a virtual tutor to labor self-promotion of Spanish workers in Europe. Proceedings of the10th Iberian Conference on Information Systems and Technologies (CISTI). doi: 10.1109/ CISTI.2015.7170579

Arnau, L., Marzo, M.T., \& Jariot, M. (2014). Learning basic employability competence: a challenge for the active labor insertion of adolescents in residential care in their transition to adulthood. European Journal of Social Work, 17(2), 252-265. doi: 10.1080/13691457.2013.802227

Banerjee, A., Galiani, S., Levinsohn, J., McLaren, Z., \& Woolard, I. (2008). Why has unemployment risen in the New South Africa? The Economics of Transition, 16(4), 715-740. doi: 10.1111/j.14680351.2008.00340.x

Battu, H., Belfield, C., \& Sloane, P. (2000). How can we measure graduate over-education and its effects?. National Institute of Economic Review, 171, 82-93.

Berridge, D. (2007). Theory and explanation in child welfare: Education and looked-after children. Child and Family Social Work, 12(1), 1-10. doi:10.1111/j.1365-2206.2006.00446.x

Brown, P., \& Hesketh, A.J. (2004). The mismanagement of talent: Employability and jobs in the knowledge economy. Oxford: Oxford University Press.
Brynin, M. (2002). Overqualification in employment. Work, Employment and Society, 16 (4), 637-54.

Cai, Y. (2013). Graduate employability: a conceptual framework for understanding employers' perceptions. Higher Education, 65, 457-469. doi: 10.1007/s10734-012-9556-x

Comunicación de la Comisión Europea. (2013). Iniciativa sobre Empleo Juvenil. Estrasburgo, 12-3-2013. Retrieved from: http://ec.europa.eu/europe2020/ pdf/youth_es.pdf

Corominas, E., Villar-Hoz, E., SaurinaCanals, C., \& Fàbregas-Alcaide, M. (2012). Construcción de un Índice de Calidad Ocupacional (ICO) para el análisis de la inserción profesional de los graduados. Revista de Educación, 357, 351-374. doi: 10-4438/1988-592XRE-2010-357-064

Crossman, J.E., \& Clarke, M. (2010). International experience and graduate employability: stakeholder perceptions on the connection. Higher Education, 59, 599-613. doi: 10.1007/s10734-0099268-z

Dixon, J. (2006). Pathways to work experience: Helping care leavers into employment. York: University of York.

Dixon, J. (2007). Obstacles to participation in education, employment and training for young people leaving care. Social Work \& Social Sciences Review, 13(2), 18-34. doi:10.1921/19648

Fachelli, S., Torrents, D., \& NavarroCendejas, J. (2014). ¿La universidad española suaviza las diferencias de clase en la inserción laboral? Revista de Educación, 364, 119-144. doi: 10.4438/1988-592X-RE-2014-364-257 
Fachelli, S., \& Navarro-Cendejas, J. (2015). Relación entre origen social e inserción laboral de los graduados universitarios. Revista ELectrónica de Investigación y EValuación Educativa RELIEVE, 21(2), art. 2. doi: http:// dx.doi.org/10.7203/relieve.21.2.7812

García-Valdecasas, J.I. (2014). El impacto de la estructura de las redes sociales sobre el acceso de los individuos al mercado laboral. Revista Internacional de Sociología, 72 (2), 303-321. doi:10.3989/ris.2012.09.13

Gutierrez, S., \& de Pablos, C. (2010). Análisis y evaluación de la gestión por competencias en el ámbito empresarial y su aplicación a la universidad. Revista Complutense de Educación, 21 (2), 323-343.

Hu, L. T., \& Bentler, P. M. (1999). Cutoff criteria for fit indexes in covariance structure analysis: Conventional criteria versus new alternatives. Structural Equation Modeling, 6, 1-55.

Jackson, D. (2016). Developing preprofessional identity in undergraduates through work-integrated learning. Higher Education, doi: 10.1007/ s10734-016-0080-2

Jung, H., Pirog, M.A., \& Lee, S.K. (2016). The long-run labour market effects of expanding access to higher education in South Korea. Journal of International Development, 28, 974990. doi: $10.1002 / \mathrm{jid} .3148$

Kalfa, S., \& Taksa, L. (2016). Employability, managerialism, and performativity in higher education: a relational perspective. Higher Education, doi: 10.1007/s10734-0160072-2

Loehlin, J.C. (2004). Latent variable models: An introduction to factor, path, and structural equation analysis ( $4^{\text {th }}$ ed.). Mahwah, NJ: LEA.
Martín, M., Rabadán, A.B., \& Hernández, J. (2013). Desajustes entre formación y empleo en el ámbito de las enseñanzas técnicas universitarias: la visión de los empleadores de la Comunidad de Madrid. Revista de Educación, 360, 244-267. doi: 10.4438/1988-592X-RE2011-360-110

Martínez-Rodríguez, F.M., \& CarmonaOrantes, G. (2010). Test de factores sociopersonales para la inserción laboral de los jóvenes: un instrumento para la evaluación y la formación Sociopersonal. Estudios sobre Educación, 18, 115-138.

Mendes, P. (2009). Young people transitioning from state out-ofhome care. Jumping hoops to access employment. Australian Institute of Family Studies, 83, 32-38.

Merino, R., \& García, M. (2007). Itineraris de formació $i$ inserció laboral dels joves a Catalunya. Barcelona: Fundació Jaume Bofill.

Muñiz, J. (2005). Utilización de los tests. En J. Muñiz, A.M. Fidalgo, E. GarcíaCueto, R. Martínez y R. Moreno (Eds.). Análisis de los items (pp. 133-172). Madrid: La Muralla, S.A.

Muthén, L.K., \& Muthén, B.O. (2007). Mplus User's Guide. Fifth Edition. Los Angeles, CA: Muthén \& Muthén.

Pérez-Sánchez, M., Trinidad-Requena, A., \& Ortega-Pérez, N. (2013). Los agentes territoriales como figura dinamizadora del proceso de la política de inserción laboral. Revista de Ciencias Sociales (RCS), XIX(1), 22-34.

Schumacker, R.E., \& Lomax, R.G. (1996). A beginner's guide to structural equation modeling. Mahwah, NJ: Erlbaum.

Serrano, G., Llamazares, F., \& Otamendi, F.J. (2015). Measurement and sustainability of the qualifications 
frameworks in the European Higher Education Area through an employment survey on access to the labour market. Sustainability, 7, 13777-13812; doi:10.3390/su71013777

Schöer, V., Rankin, N., \& Roberts, G. (2014). Accessing the first job in a slack labour market: job matching in South Africa. Journal of International Development, 26, 1-22. doi: 10.1002/ jid. 2838

Schomburg, H. (2007). The Professional Success of Higher Education Graduates. European Journal of Education, 42 (1), 35-57.

Silva, P., Lopes, B., Costa, M., Seabra, D., Melo, A., Brito, E., \& Paiva Dias; G. (2016). Stairway to employment? Internships in higher education. Higher Education, 72, 703-721. doi: 10.1007/s10734-015-9903-9

Sin, C., \& Amaral, A. (2017). Academics' and employers' perceptions about responsibilities for employability and their initiatives towards its development. Higher Education, 73, 97-111. doi: 10.1007/s10734-0160007-y

Tomlinson, M. (2008). 'The degree is not enough': students' perceptions of the role of higher education credentials for graduate work and employability. British Journal of Sociology of Education, 29(1), 49-61. doi: 10.1080/01425690701737457

Trede, F., \& McEwen, C. (2015). Early workplace learning experiences: what are the pedagogical possibilities beyond retention and employability? Higher Education, 69, 19-32. doi: 10.1007/s10734-014-9759-4

Verick, S. (2009). Who Is Hit Hardest during a Financial Crisis? The Vulnerability of Young Men and Women to Unemployment in an Economic Downturn. IZA Discussion Paper No. 4359. 


\section{PERFIL ACADÉMICO Y PROFESIONAL DE LOS AUTORES}

PhD Joan Guàrdia-Olmos is a Professor in the Department of Social Psychology and Quantitative Psychology in the Psychology Faculty (University of Barcelona). His academic activity is related to Statistical Data Analysis. He teaches this topic to several grades and postgraduates courses in national and international universities. He is the head of the Group for Academic Innovation «Grup pel desenvolupament de l'aprenentatge de l'estadística en salut GIDCUB-13/079»; and of the Consolidated Research Group «Psicologia Quantitativa 2017SGR269».

PhD Maribel Peró-Cebollero is a full time teacher in the Department of Social Psychology and Quantitative Psychology in the Psychology Faculty (University of Barcelona). She teaches subjects related to statistics and epidemiological studies in graduate and postgraduate courses. She is a member of the Group for Academic Innovation «Grup pel desenvolupament de l'aprenentatge de l'estadística en salut GIDCUB-13/079»; and of the Consolidated Research Group «Psicologia Quantitativa 2017SGR269».

Mar Martínez-Ricart is psychologist and master degree in Neuroscience for the University of Barcelona. She has worked as assistant research in the Department of Behavioral Sciences of the Faculty of Psychology and in the Open University of Catalonia (UOC). She also has worked psychologist and customer service manager at Psious.

Cristina Cañete-Massé is a psychologist and has a masters degree in General Sanitary Psychology. She is a research assistant at the departmental section of Quantitative Psychology in the Faculty of Psychology of the University of Barcelona.

PhD Jaume Turbany-Oset is a full time teacher in the Department of Social Psychology and Quantitative Psychology in the Psychology Faculty (University of Barcelona). His academic activity is related to Statistical Data Analysis. Consultant of the UOC (Open University of Catalonia). Tutor of the UNED. He is a member of the Group for Academic Innovation «Grup pel desenvolupament de l'aprenentatge de l'estadística en salut GIDCUB-13/079»; and of the Consolidated Research Group «Psicologia Quantitativa 2017SGR269».

$\mathrm{PhD}$ Vanesa Berlanga-Silvente is a part-time teacher in the department of Research Methods and Diagnostics in Education in the University of Barcelona and an assistant professor in the University Abat Oliva. She is a member of the research group Entrepreneurship, strategy and business competitiveness (GREECE), of the Association of Economy in Education (AEDE) and of the 
Catalan Society of Statistics (SCE). Her lines of research are related to the living conditions of university students and university funding.

Dirección de los autores: Secció departamental de Psicologia Quantitativa

Departament de Psicologia Social i

Psicologia Quantitativa

Facultat de Psicologia

Passeig de la Vall d'Hebron, 171

08035 Barcelona (Spain)

E-mail: jguardia@ub.edu

mpero@ub.edu

mar.martinez.ricart@gmail.com

cristinacanete@ub.edu

jturbany@ub.edu

berlanga.silvente@ub.edu

Fecha Recepción del Artículo: 07. Octubre. 2017

Fecha Modificación del Artículo: 25. Enero. 2018

Fecha Aceptación del Artículo: 10. Febrero. 2018

Fecha Revisión para Publicación: 22. Febrero. 2018 